\title{
Using Mobile Banking Services to Improve Financial Access for the Poor: Lessons from Kenya, the Philippines, the United States, Haiti, and India
}

\author{
By Kanika Metre
}

As the number of mobile phone subscriptions has rapidly expanded in developing countries, so too has the use of mobile phones to facilitate small-scale financial transactions around the world. Microfinance experts have recognized these mobile banking services as a means for expanding access to financial services among poor and low-income populations. Innovations over the past few years have proven that mobile network operators and banks can cooperate to create successful business models for mobile banking services. Recognizing this success, this paper further explores the ways in which private sector, public sector, and non-profit sector actors can and should collaborate to meet the financial service needs of the poor through innovations in mobile banking. Case studies from Kenya, the Philippines, the United States, Haiti, and India provide relevant lessons on how these collaborations have succeeded or failed in the past.

\section{Introduction}

By the end of 2010, International Telecommunication Union estimates placed mobile phone coverage at 90 percent of the world population with 5.3 billion people using mobile phones worldwide (ITU 2010). Now as the market for mobile phones usage is becoming saturated in developed countries, the most significant levels of growth are being seen in developing countries (ITU 2010). Rapid advancements in technology, however, are not necessarily linked with economic prosperity. Indeed, a growing percentage of the billions of individuals who have access to mobile phone coverage also live in poverty. As of 2005, the World Bank calculated that 2.5 billion people, or about 40 percent of the world's population, lived on an income of two dollars per day or less (Collins et al. 2009). ${ }^{1}$ While the spread of technology in itself cannot be considered an indicator for increased distribution of wealth, significant opportunities do exist for utilizing technological innovations to advance international development goals of reducing world poverty. This paper assesses the financial needs of the poor, explains how mobile phones can meet these needs, and analyzes how mobile money has worked in practice. Ultimately, this paper provides recommendations on the roles that private sector, public sector, and non-profit sector actors should play in order to expand access to financial services to the poor through mobile money.

When microfinance, the provision of financial services targeting low-income clients and those who lack access to formal banking services, first became popular in the 1970s, service providers largely focused on a standard location-based branch-and-loan-officer model. With the spread of modern communications technology, innovations have driven new products delivered through the Internet, call centers, prepaid cards, ATMs, banking 
agents, and mobile phones (Saxena 2009). In particular, banks and mobile phone service providers in many developing countries have begun collaborating to capitalize on national surges in mobile phone usage. This collaboration has made financial services accessible through mobile phones, which allow financial services to take place at local retail outlets in areas where bank branches do not exist. Mobile money service providers are capable of both cutting down transaction costs and extending access to formal financial services to individuals who would not otherwise have such access. Within the last decade, more than 100 different mobile money services have been introduced in 59 countries. Of these, more than 60 percent were launched in 2009 and 2010 and ten additional mobile money service providers are scheduled to launch in 2011 (GSM Association 2011). In short, mobile money is taking off fast.

As more banks and mobile phone service providers collaborate to produce new mobile banking services, microfinance advocates have increasingly considered these partnerships as a method of expanding access to financial services to the poor. Recently, however, microfinance institutions have also come under fire for being primarily profit driven, and for failing to make measurable positive effects on health, education, or women's decisionmaking, despite common claims that microfinance services provide such benefits (MacFarquhar 2010; Banerjee et al. 2010). Other studies have questioned the extent to which mobile banking services are actually used by clients who previously did not have access to regulated bank services, rather than serving as an additional means of accessing money for those who already have bank accounts (Ivatury and Mas 2008). With these concerns in mind, both governments and non-governmental organizations (NGOs) have a responsibility to monitor the extent and manner through which mobile banking services affect the low-income and poor populations that they serve. Building on these findings, governments and NGOs should then actively seek out opportunities to collaborate with the private sector to enact policies and programs that best serve the needs of the poor.

\section{Microfinance and the Need for Formal Financial Services among the Unbanked Poor}

Before discussing how different sectors can collaborate to improve financial access to the poor, it is critical to have a basic understanding of the financial needs of the poor. In Portfolios of the Poor, Collins et al. (2009) examine how the world's poor live on two dollars per day. Low income is only one factor contributing to the struggles the poor face, and thus it is crucial to also consider how irregular and unpredictable incomes affect those in the largest and poorest socio-economic group at the bottom of the pyramid. Even when the poor have secured informal jobs, their paychecks are often inconsistent or uncertain. Since incomes are not earned at a fixed two dollars per day, the need for access to reliable financial services is more severe (Collins et al. 2009).

In their research, Collins et al. (2009) identify three key financial needs of the poor: the ability to manage irregular cash flows, the ability to cope with risk, and the ability to raise lump sums when called for on specific occasions. In addition to identifying these needs, Collins et al. (2009) provide numerous examples of how the poor already manage their finances, often using a wide variety of informal and formal channels, rather than simply living from hand to mouth as typically understood. In an earlier survey of the household economies and daily politics of 40 Grameen Bank loan recipients, Helen Todd (1996) noted how women often had found ways to save small amounts of cash, build assets, and borrow and lend from other women before they joined the Grameen Bank. Others such as Rutherford (2001) and Armendáriz de Aghion and Morduch (2005) have reported similar 
findings in their studies of how the poor manage their money.

When considering the services needed and used by the poor, it is important to distinguish between formal and informal financial services. The critical difference is in regulation and structure. Examples of informal financial services may include a loan from a local non-institutional moneylender, sending remittances home through a truck driver, savings held with a money guard, savings hidden at home or held for others, and shopkeeper credit. In contrast, examples of formal financial services used by low-income groups may include microfinance savings accounts, microfinance loan accounts, life insurance, or any financial service that is formally regulated (Collins et al. 2009). While all communities are capable of utilizing informal means of managing money, the poor are often limited to unregulated forms of financial services. Since forms of financial services can be valuable to the poor depending on specific circumstances, being among the unbanked poor indicates a lack of access to a full range of financial services and the choices that such access provides.

When microfinance was established in the 1970s, the focus was on microcredit programs that offered loans for investing in small businesses. In subsequent years, other financial products such as microsavings and microinsurance have developed to meet the financial needs of the poor. Additionally, services that permit individuals living away from their families to send cash remittances home were created in response to high demand for these services among migrant workers. Around the world, different formal channels facilitate regulated transfers of both international remittances between countries and domestic remittances sent from urban areas to rural areas within countries. Despite these advancements, an estimated 4 billion people worldwide in 2008 were unbanked, meaning they were without access to formal financial services (Pickens 2009). Without access to formal financial services, the billions of unbanked are limited to using informal and unregulated means of managing their money.

While demand generally exists among the poor for more reliable and lower-priced formal financial services, it is often not met. Regulated private sector institutions may believe it is not cost-effective to provide such services on a "micro" scale, often in more remote areas with less established infrastructure. Increasingly, private sector actors have sought out cost-effective methods for reaching new markets. As a result, the poor are increasingly making use of a wide range of both formal and informal services to manage their money.

In order to both meet the needs of the poor and be cost-effective, financial service providers targeting the poor must understand the unique needs of the poor. The wide range of informal and formal

Table 1: Poverty Rates, Mobile Phone Subscriptions, and Internet Usage by Country.

\begin{tabular}{|c|c|c|c|}
\hline Country & $\begin{array}{c}\text { Poverty headcount } \\
\text { ratio at \$2 per day } \\
\text { (2005 PPP) } \\
\text { (\% of population) }\end{array}$ & $\begin{array}{c}\text { Mobile phone } \\
\text { subscriptions per } \\
\text { 100 people (2009) }\end{array}$ & $\begin{array}{c}\text { Internet users } \\
\text { per 100 people } \\
\text { (2009) }^{\mathbf{2}}\end{array}$ \\
\hline Kenya & $39.9(2005)$ & 48.7 & 10.0 \\
\hline Philippines & $45.0(2006)$ & 100.3 & 9.0 \\
\hline United States & - & 90.8 & 78.0 \\
\hline Haiti & - & 36.4 & 10.0 \\
\hline India & $75.6(2005)$ & 43.8 & 5.1 \\
\hline
\end{tabular}

Source: ${ }^{1}$ World Bank 2011. ${ }^{2}$ ITU 2011. 
mechanisms used by the poor show that while the poor face a wide range of financial needs, they have developed responses to meet those needs. However, major challenges remain. Specifically, informal finance services are usually unreliable, lack transparency, and have a number of financial and non-financial costs (Collins et al. 2009).

Using these findings, Collins et al. (2009) conclude that there are four key principles for policymakers and microfinanciers to focus on when developing formal financial services for the poor: reliability, convenience, flexibility, and struc- ture. These factors need to be assessed when designing formal microfinance services for the poor, and new methods for expanding financial inclusion. Not only should reliability, convenience, flexibility, and structure be characteristics of formal banking services, but these ideas should also be central to mobile money services that attempt to increase access to a full range of financial services among the poor.

\section{The Growth of Mobile Phone Usage and Mobile Money}

Mobile phones provide a particu-

Figure 1: Mobile Phone Subscriptions and Internet Users in High-Income and Developing Countries.

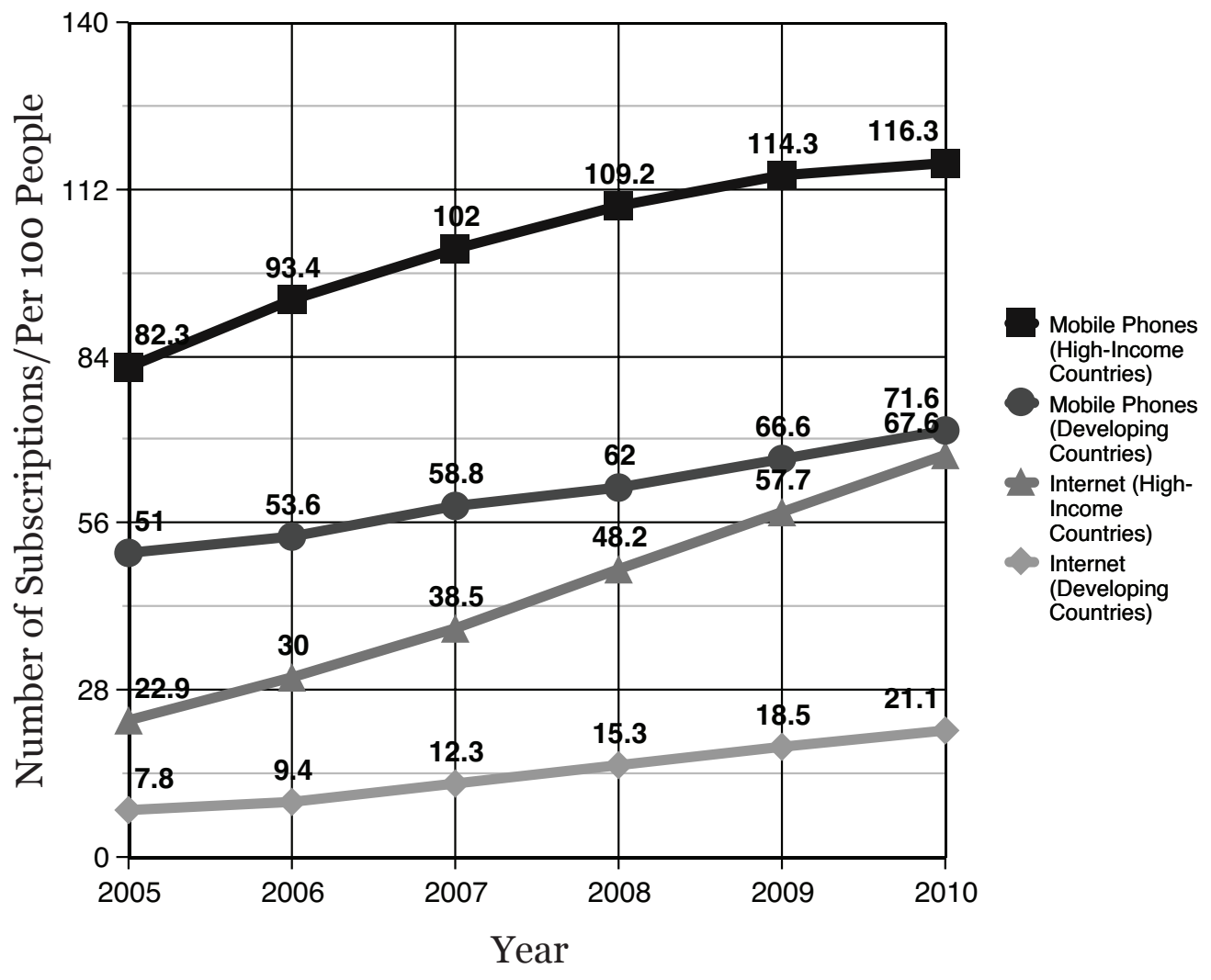

Source: ITU 2011. 
larly successful means for expanding the communication capacity and access to formal financial services for the poor in many developing countries. In 2009, estimates show that there were 1 billion people globally who did not have a bank account but owned a mobile phone (Greenwood 2009). In developing countries in particular, mobile phone usage has increased far more rapidly in recent years than Internet usage. As seen in Table 1, the disparity between mobile phone usage and Internet usage is particularly clear in the case of the Philippines, where there are more than 100 mobile phone subscriptions per 100 people but only nine Internet users per 100 people. In contrast, mobile phone usage in the United States is actually lower than in the Philippines, but mobile phone usage is not much higher than Internet usage in the United States.

Most significantly, as seen in Figure 1, mobile phone usage has been increasing at a higher rate in developing countries than either mobile phone usage or Internet usage among high-income countries. Between 2005 and 2010, the average number of mobile phone subscriptions in developing countries tripled from about 23 subscriptions per 100 people to nearly 68 subscriptions per 100 people (2010 data are based on estimates). Internet use has also grown in developing countries, but it is still low relative to the number of mobile phone subscriptions. In 2010 the average number of Internet users in developing countries was estimated to be only 21 percent of the total population.

The Consultative Group to Assist the Poor has estimated that by 2012, as many as 364 million low-income and otherwise unbanked individuals will likely utilize mobile money services. Additionally, since mobile banking cuts transaction costs, the mobile money industry may generate up to $\$ 7.8$ billion in revenues (Pickens 2009). If these predictions are correct, the demand for services and the ability of providers to make profits could make the mobile money enterprise a sustainable method for providing formal financial services to the poor.

The process of banking though mobile phones is relatively simple. Mobile banking allows customers to pay for financial transactions at local venues, similar to pay-as-you-go mobile phone plans in which airtime is purchased at local stores. For example, a mobile banking customer may go to a corner store and deposit money into a mobile banking account by providing the manager of the store with his or her unique mobile banking PIN code. The store manager then records the transaction electronically and takes the deposit on behalf of the bank. After the transaction, the mobile banking customer receives a text message receipt for the transaction.

Figure 2: Mobile Money Photo.

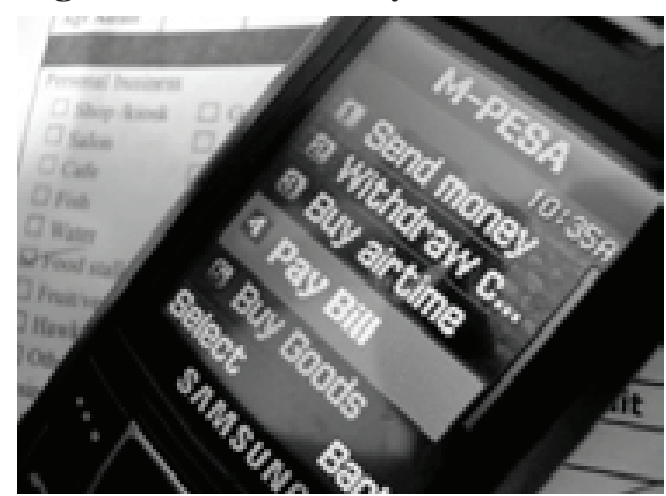

Source: Jeremy Gordon 2010.

As mobile phone use has expanded in developing countries, banking agents now play an important role in facilitating mobile banking. Banking agents are third party retail outlets that process financial transactions on behalf of banks and other licensed-deposit taking institutions (Mas and Siedek 2008). Depending on the country, banking agents may include post offices, lottery dispensaries, pharmacies, fast food chains, supermarkets, and department stores. Utilizing banking agents in poorer areas where transactions are generally of lower value allows banks 
to provide small-scale financial services while avoiding the high costs of operating bank branches. Records provided through text message receipts and authorizations produced using PIN codes can both be generated by local bank agents using mobile phones. As a result the clients retain quick and easy access to their bank accounts.

Mobile phones and third party retail outlets have been coupled successfully to create channels for sending and receiving remittances. These regulated mobile services for transferring remittances are generally cheaper and more reliable for the clients, addressing a key need outlined earlier (Saxena 2009; Mas and Morawczynski 2009). In many developing countries where these services exist, remittances are often an important source of financial support for families while also making up a significant proportion of national wealth. For example, the Philippines received $\$ 215$ per person in remittances in 2009, and remittances made up 12 percent of the Philippines' GDP in 2007 (United Nations Development Programme 2009).

While the high demand for formal remittance sending services has formed the starting point for many mobile banking services, mobile phones are also now used to extend a wider variety of financial services to the poor. In two countries, Kenya and the Philippines, mobile phone operators and banks have been particularly successful in creating a variety of sustainable and often profitable mobile banking services. Moreover, as mobile banking has become increasingly popular in developing countries, US-based global money transfer service companies have also begun to incorporate the mobile banking model. These trends show that the concept of mobile money appears to be growing in popularity among a wide range of private sector actors.

Case studies of five countries can help illustrate the extent to which mobile banking initiatives have met with success, the challenges that other mobile banking initiatives still need to overcome, and the roles played by the non-profit and public sectors in each country. The case studies include Kenya, the Philippines, the United States, Haiti, and India. In Kenya and the Philippines, it is important to note the roles that public sector and non-profit sector institutions have had in the success of mobile banking. In other countries, such as India, the potential for the public sector to negatively affect mobile banking is clear. With countries that lack stable government structures, such as Haiti, we see how the non-profit sector can provide support for mobile banking when the public sector is incapable of doing so.

\section{Case Studies: Mobile Banking Opportunities and Challenges}

\section{Kenya}

Arguably, the most successful example of how technology has helped expand financial access for the poor can be found in Kenya's M-PESA service. M-PESA allows Kenyans to make cash withdrawals, deposits, and transfers all through their mobile phone. The concept behind M-PESA originally began in 2003 as a pilot project funded by Vodafone and the United Kingdom's Department for International Development to test a mobile phone-based solution for making financial transactions in remote parts of Kenya and Tanzania (DFID 2008). After the success of the pilot project, in March 2007 Safaricom (Vodafone's mobile phone operator in Kenya) and Equity Bank partnered to launch M-PESA. By May 2010, 9.5 million customers had registered for M-PESA, representing over 45 percent of Kenya's adult population and twice the number of Kenyans with bank accounts (Microfinance Focus 2010). The service could be accessed through over 16,000 retail outlets in rural and urban areas nationwide (McKay and Pickens 2010; Jack and Suri 2010a). These retail outlets include air- 
time resellers, bank branches, and some larger supermarket chains (Mas and Morawczynski 2009). Though the service grew largely out of a significant gap in the domestic remittance market, expansion into other services has taken place.

In March 2010, Safaricom partnered with the Syngenta Foundation for Sustainable Agriculture and UAP Insurance to provide a crop insurance product, Kilimo Salama, for Kenyan farmers to insure their crops against weather risks. Through a combination of the M-PESA mobile money service, 30 automated solar-powered weather stations that detect weather conditions, and camera phones that scan bar codes for each bag of seed, fertilizer, and herbicide bought, farmers can register and pay for crop insurance at their nearest weather station (The Economist 2010a).

M-PESA was originally marketed solely as a remittance service because banking regulations prohibited non-bank institutions from accepting savings. In spite of this, 21 percent of M-PESA users in 2008 still listed the service as their main way to save (Pickens 2010). After these statistics were made public in 2009, new agent banking regulations established by the Central Bank of Kenya in May 2010 led to the formation of M-KESHO, a product that allows interest-collecting savings accounts to be set up with Equity Bank through Safaricom's mobile network. These accounts do not have account opening fees, minimum balance requirements, or monthly charges.

The success of M-PESA and subsequent development of new and innovative services by Safaricom and its partners has been attributed to a number of factors. M-PESA's rapid rate of expansion has largely been attributed to the well-established client base and network of sale points established by Safaricom and Equity Bank. Other factors leading to M-PESA's success are that standardized customer registration forms are easy to fill out, text-message receipts are provid- ed to customers, services are tracked on agent logs, and retail pricing is simple and transparent. Additionally, services provided meet customer needs including free deposits, no minimum balance, the ability to send money to non-customers, and one-time authorization codes that enable ATM withdrawals in place of bankcards (Mas and Morawczynski 2009). In short, the services are transparent, affordable, reliable, and easily accessible, meeting the criteria set out in this paper for mobile money services that meet the needs of the poor.

While the services provided through M-PESA appear to provide opportunities for those without formal bank accounts to access financial services, not all M-PESA users are unbanked. In fact, a September 2008 survey estimated that only 25 percent of M-PESA users were actually unbanked (Jack and Suri 2010a). In other words, an estimated 75 percent of M-PESA users also held bank accounts outside of their mobile banking services. While the estimated percentage of unbanked M-PESA clients rapidly increased from 25 percent to 50 percent in late 2009, there still appear to be significant opportunities for expanding the reach of M-PESA services to those who would otherwise rely solely on informal money management methods (Jack and Suri 2010a).

Just as government agencies such as the Department for International Development and the Central Bank of Kenya have been instrumental to the continued success of M-PESA, the non-profit sector has also been involved in building on and evaluating M-PESA's success. In addition to the Syngenta Foundation's role in developing crop insurance, the country's largest microfinance institution, Jamii Bora, has also signaled interest in capitalizing on the expansion in mobile phone usage to reach clients living in remote areas. Already, Jamii Bora has begun utilizing an online financial transaction system through which clients can make loan repayments, receive disbursements, and access other 
financial services through a hand held mobile point-of-sale device (Christensen and Thomas 2010).

Economists from Georgetown University and MIT have begun to identify the socio-economic characteristics of M-PESA users over time and in comparison to non-M-PESA users. This is another example of how the non-profit sector can contribute to understanding how mobile banking services can most effectively increase access to financial services among the poor. The data collected includes the number of M-PESA clients that were previously unbanked, as well as the number of clients from rural areas. Other characteristics measured include saving behaviors, wealth, education levels, and literacy of clients and of the heads of households in which M-PESA is used. The gender and age of individual M-PESA clients were also recorded (Jack and Suri 2010a; Jack and Suri 2010b). Though understanding all of these characteristics may not be a priority within the private sector, this information allows all interested groups to learn which socio-economic groups are utilizing mobile banking, and which groups still have limited access to financial services.

\section{The Philippines}

Though M-PESA may be the most publicized success story in mobile money thus far, Kenya is not the first country where mobile phones have made financial services more available to poor people. In the Philippines, where 75 percent of the country was without access to formal financial services in 2009, two mobile money services produced by communications companies predate M-PESA. Smart Communications' SMART Money and Globe Telecom's GCASH Mobile were launched in 2001 and 2004, respectively (Pickens 2009). As with M-PESA, these mobile money services began largely with remittances. However, one-third of Filipino mobile money clients in 2009 did not use these services to transmit or receive remittances at all. Considering that 98 percent of Filipinos without formal bank accounts receive their income in cash, it is not surprising that mobile money services are used to receive salary and payments. Mobile money is also an alternative to informal savings instruments, in response to the fact that 52 percent of surveyed clients in 2009 relied in part on hiding cash at home (Pickens 2009).

Despite the widespread use of mobile money services as informal savings instruments, SMART Money and GCASH still do not provide formal savings instruments. However, both SMART Money and GCASH now facilitate merchant payments and loan disbursements, in addition to both domestic and international remittance transfer services. Additionally, SMART Money provides bill payment and loan disbursement services, while GCASH provides salary disbursement services and enables deposits and withdrawals authorized by text (GSM Association 2010).

Like M-PESA, not all SMART Money and GCASH clients are unbanked. In fact, both Smart and Globe have developed services specifically for clients who already have established bank accounts, which allow such clients to transfer money between their mobile money accounts and their bank accounts. Though this service may appear to target banked customers, allowing banked customers to easily transfer money from bank accounts to mobile money accounts in turn encourages financial transactions between banked and unbanked customers. As such, making mobile money services more appealing to banked customers should also lead to greater access to financial transactions for unbanked customers (Leishman 2009).

SMART has partnered with private bank Banco de Oro to facilitate financial transactions for its mobile accounts, similar to Safaricom's partnership with Equity Bank in Kenya. In contrast, Globe has secured approval from the Central Bank of the Philippines to perform the bank-like functions necessary to implement GCASH without a banking license or 
direct partnership with a bank. This has been made possible in part by The General Banking Law of 2000, which requires the Filipino government to promote and support a stable and efficient financial system that includes microfinance as a legitimate banking activity. The General Banking Law of 2000 has also led to the formation of a special unit within the central bank to oversee the use and development of mobile commerce. In the case of Globe, the Central Bank of the Philippines has required that Globe submit regular reports that show that each peso of GCASH is backed up in a bank account (Rhyne 2009). The General Banking Law of 2000 also specifically references regulation procedures for the microfinance sector:

The Monetary Board shall regulate the interest imposed on microfinance borrowers by lending investors and similar lenders, such as, but not limited to, the unconscionable rates of interest collected on salary loans and similar credit accommodations (Republic Act No. 8791, 2000).

Through the formation of The General Banking Law of 2000, the Central Bank of the Philippines provides an example of how a government agency can significantly contribute to both the development and regulation of mobile banking services that further support client protection in microfinance.

The Central Bank is not the only government agency to work with Globe, however. The Department of Social Welfare and Development, in partnership with the Land Bank of the Philippines, is currently working with Globe to implement the government's pilot Conditional Cash Transfer Program. In this program, a Globe product called GCASH REMIT will be used to distribute cash grants to poor families living in remote areas. The Conditional Cash Transfer Program is structured to provide access to health services, nutrition, and education to poor families and is central to the Filipino government's poverty alleviation plan (Globe 2011).

Within the non-profit sector, universities and humanitarian organizations have also partnered with Globe to implement the GCASH payment system (Rhyne 2009). Most recently, the United Nations World Food Programme has collaborated with Globe in using GCASH to implement a cash-for-work program that assists Filipino families that have been displaced by typhoons, rising sea levels, and conflicts (CNN 2011). Through partnerships with national and multilateral agencies, forprofit mobile banking service providers in the Philippines have made a positive social impact among Filipino communities in need of both formal financial services and more direct means of poverty relief.

\section{The United States}

Developing countries such as Kenya and the Philippines are not the only places where significant portions of the population remain unbanked. In fact, nearly 30 million households in the United States do not have a bank account or rarely use a bank account (Mui 2011). This number represents about a quarter of all American households (US Census Bureau 2010). This trend correlates with income as approximately 70 percent of these unbanked households earn less than $\$ 30,000$ per year (Mui 2011). Retailers in the United States such as Kmart, Best Buy, and Wal-mart have begun filling this gap by providing in-store transactions such as check cashing, money transfers, and bill pay services (Mui 2011).

While providing the unbanked with financial services through retailers is a relatively new phenomenon in the United States, transferring remittances across the world using US-based global money transfer companies such as Western Union and MoneyGram is a well-established practice. Not surprisingly, these companies have also taken notice of the rapid speed with which mobile phone usage has recently been increasing in the developing world. In 2008, Western Union 
worked with Smart Communications and Globe Telecom to allow Western Union clients in Hawaii, the United Arab Emirates, Hong Kong, and Singapore to transfer money directly to SMART Money and GCASH accounts. With 445,000 Western Union agents currently operating in over 200 countries, Western Union aims to expand its Mobile Money Transfer services by partnering with mobile money service providers around the world (Western Union 2010). MoneyGram has also begun using mobile phones to deliver remittance services. A partnership formed with Affinity Global Services in 2009 will allow MoneyGram to provide cash transfer services to mobile devices from an alreadyestablished network of over 180,000 agent locations worldwide (Crook 2009).

Global money transfer companies are not the only businesses in the United States to make use of mobile money services. Two companies specializing in mobile payment systems, Obopay and Monitise Americas, were formed in the United States in 2005 and 2007, respectively. Both Obopay and Monitise Americas, however, appear to target banked clients with services that facilitate bank account management, domestic money transfers, and bill payments (GSM Association 2011). Still, the formation of these companies reveals that potential may exist outside of developing countries for using mobile phones to expand access to formal financial services.

As with Kenya and the Philippines, the US federal government plays an important role in both encouraging and regulating mobile banking as a means for expanding access to a full range of financial services. When Muhammad Yunus, founder of Grameen Bank, began adapting the village banking model he used in Bangladesh to meet the needs of poor communities in the United States, he found that his greatest obstacle was American welfare law. While many of the poor he spoke with in Illinois had entrepreneurial ideas for using the loans he offered, welfare recipients were not allowed to take out loans.
The state of Illinois later amended its laws such that welfare recipients could borrow money (Yunus 1999). Yunus's problematic experience with welfare laws in the United States provides a clear example of how government policies can significantly affect microfinance programs. In order for mobile banking to be successful in the United States, supportive government policies should be formulated and implemented to truly help the poorest of the poor. Just as the Central Bank of the Philippines has provided support for mobile commerce and microfinance through recent legislation, the United States may be able to encourage and regulate mobile banking services through federal agencies such as the newly created Consumer Financial Protection Bureau.

\section{Haiti}

In July 2009, the US Agency for International Development (USAID), in partnership with non-profit organizations AED, World Council of Credit Unions, and Technoserve, established the Haiti Integrated Finance for Value Chains and Enterprises (HIFIVE). Prior to the Haiti earthquake of 2010, HIFIVE had already instituted a Microfinance Sector Information and Communications Technology solutions working group to increase financial inclusion in Haiti (Bold 2011; microLINKS 2009). After the earthquake, with twothirds of Haiti's banks destroyed, utilizing mobile financial services became an even bigger focus of HIFIVE. As the United Nations World Food Programme is now doing in the Philippines, HIFIVE also used mobile network operators to facilitate transfers of funds for cash-for-work programs.

Though HIFIVE and M-PESA both began with support from donor country aid agencies, non-profit organizations and specifically foundations have also been instrumental in funding mobile money initiatives. For example, five months after the 2010 earthquake the Bill and Melinda Gates Foundation and USAID created a 
$\$ 10$ million fund for mobile banking services in the country (BBC News 2010). On January 10, 2011, the newly founded Haiti Mobile Money Initiative made its first award of \$2.5 million (Bold 2011). Digicel's Tcho Tcho Mobile received the award as a result of being the first Haitian mobile banking service to meet HIFIVE's requirements of having operations in 100 locations with 100 agents each conducting 100 cash-in/cash-out transactions for a total of 10,000 transactions (Taylor 2011).

While the actual implementation of mobile banking services has been dominated by the private sector, NGOs are slowly beginning to employ these services to execute relief and development programs. In September 2010, Mercy Corps teamed up with a Haitian wireless operator, Voíla, and Haiti's largest bank, Unibank, to create mobile money services that specifically support Mercy Corps programs. This partnership resulted in recipients of Mercy Corps' cash-for-work payments, grants, and food vouchers being able to receive these funds through their Voíla mobile phones (Trilogy International Partners 2010). Mercy Corps and TCash, Voíla's mobile banking service that was launched in December, also provide similar withdrawal and transfer services to Digicel.

The potential for mobile money services in Haiti has received particular attention because of the country's massive need for immediate assistance, but the partnership between NGOs and private sector mobile phone service and bank service providers can be applied in other countries as well, as can be seen by the cash-for-work programs that have recently begun in the Philippines. Though further analysis on the impact of these programs is needed, similar partnerships could be effective in other developing countries and with other international relief and development NGOs and intergovernmental organizations.

Additionally, using technology providers and banks to distribute financial resources might provide relief assistance in both developing and high-income countries. For example, since US businesses have already begun to use mobile money service models, it seems feasible that models such as those implemented through Voíla, Unibank, and Mercy Corps could also help address the effects of natural disasters such as Hurricane Katrina in New Orleans. In order to assess the potential opportunity for collaboration across countries, more research is required on how mobile money service successes can be expanded to support public and non-profit sector agents working towards economic and social development services around the world.

\section{India}

With a population of over 1 billion people, 75 percent of whom live on less than two dollars per day (see Figure 1), it is not surprising that microfinance found a large market in India. In fact, by 2010, the country had become home to nearly 27 million microfinance clients, almost three times the number of people living in Haiti (The Economist 2010b). As private banks entered the microfinance market and clients increasingly took out loans from multiple banks at a time, over-indebtedness became a larger problem. In October 2010, turmoil broke out in the southern Indian state of Andhra Pradesh as local government officials and politicians began encouraging thousands of borrowers to default on their loans. In the month of October alone, collection rates in Andhra Pradesh fell from 98 percent to less than 20 percent, rapidly bringing the microfinance industry to a halt (Kazmin 2011). As a result, the biggest microfinance banks did begin capping their interest rates around 24 percent partially in response to local government officials' allegations that such banks were encouraging over-indebtedness (Bellman and Chang 2010).

In addition to the saturation of the microfinance market and the high interest rates being charged, one of the main problems leading to the crisis was the lack 
of productive collaboration between private microfinance banks and local public sector officials. Part of this may have been because the success of microfinance banks had reduced local politicians' ability to reward individuals for their electoral support using rural credit (The Economist 2010b). However, Elisabeth Rhyne (2010) allocates much of the blame to the public policy environment in India, starting with the socialist reforms of the 1990s, which led to a national focus on public sector banks at the expense of private sector banks and microfinance. Specifically, Rhyne notes that microfinance institutions could not legally receive licenses to take deposits, in part because of the competition they could create for public sector banks. Without these licenses, microfinance institutions had no incentive to provide savings services and thus were left with unbalanced portfolios (Rhyne 2010).

The focus in the aftermath of the crisis has largely been on restraining unsustainable rapid growth of microfinance banks, building better client protection practices, and forming credit bureaus (Rhyne 2010). In response to the crisis, the Reserve Bank of India set up a special committee to study the microfinance industry's practices and provide recommendations for productive changes. The committee has since recommended that microloans to the poor be capped at 25,000 rupees (\$500) per borrower, employ flexible repayment schedules, and have interest rates capped at 10 or 12 percent depending on the size of the microfinance institution (Kazmin 2011). In this manner, the Indian government encourages the development of microfinance services in line with flexibility and structure, two previously outlined needs of the poor, and particularly a structure that supports client protection from over-indebtedness.

While this crisis was not directly linked to mobile banking services, the crisis offers lessons about the importance of productive collaboration between public and private sector actors as mobile bank- ing becomes more popular in India. In January 2011, India's largest public sector bank and its largest private sector bank both announced partnerships with mobile phone operators to begin providing mobile banking services (Rotman 2011). Vikram Akula (2009), founder of SKS Microfinance, India's fastest growing microfinance institution and one of the banks affected by the crisis in Andra Pradesh, has often argued that while mobile banking is crucial for increasing security and cutting costs in microfinance, government policies have prohibited mobile banking in microfinance from becoming a reality. In particular, Akula has highlighted the Reserve Bank of India regulations that bar non-bank institutions from handling bank transactions on behalf of clients or accepting deposits. Akula also points out government initiatives to expand financial inclusion for which government-published results make the initiative appear significantly more successful than results for the same initiative published by independent surveyors. In short, the government needs to include the private sector in its efforts to expand financial inclusion (Akula 2009).

\section{Analysis and Implications: Designing Social Development- Oriented Banking Services}

\section{Potential for Mobile Banking to Meet the Financial Needs of the Poor}

As the above case studies show, mobile banking has rapidly expanded not only in countries where the total number of phone subscriptions is slightly greater than the national population (the Philippines), but also in countries with a little under one cell phone subscription for every two people (Kenya). Though mobile phone subscriptions are slightly less common in Haiti and India than in Kenya, potential exists in these countries to successfully incorporate mobile banking into the range of formal financial services currently offered. Still, Kenya, Haiti, and India each have fewer mobile subscrip- 
tions per 100 people than the average rate among developing countries, which was 57 subscriptions per 100 people as of 2009 (ITU 2011). Though the proliferation of mobile phone usage is not the only factor needed for mobile banking to be successful, the rapid growth in mobile phone subscriptions among developing countries suggests that mobile banking can become a tool for reaching remote populations in developing countries around the world. At the same time, cases such as the United States show that mobile banking may help expand access to financial services among the poor of high-income countries as well.

Still, two major country-by-country factors must be considered when determining whether mobile banking can successfully increase access to formal financial services for the unbanked poor.
The first factor is whether mobile banking services can generate enough profit to be sustainable given country-specific contexts. In Kenya and the Philippines, mobile banking services implemented by the private sector have grown rapidly with support from the public and non-profit sectors. However, the sustainability of these mobile banking models does not indicate that the financial needs of the poor are fully being met. The second factor is to consider the three key financial needs of the poor outlined earlier: the ability to manage irregular cash-flows, the ability to cope with risk, and the ability to raise lump sums when called for on specific occasions. The extent to which these three key financial needs are met by mobile banking services will depend largely on the range of financial services made available through mobile banking. Successful models should

Figure 3: Mobile Banking Cross-Sector Collaboration.

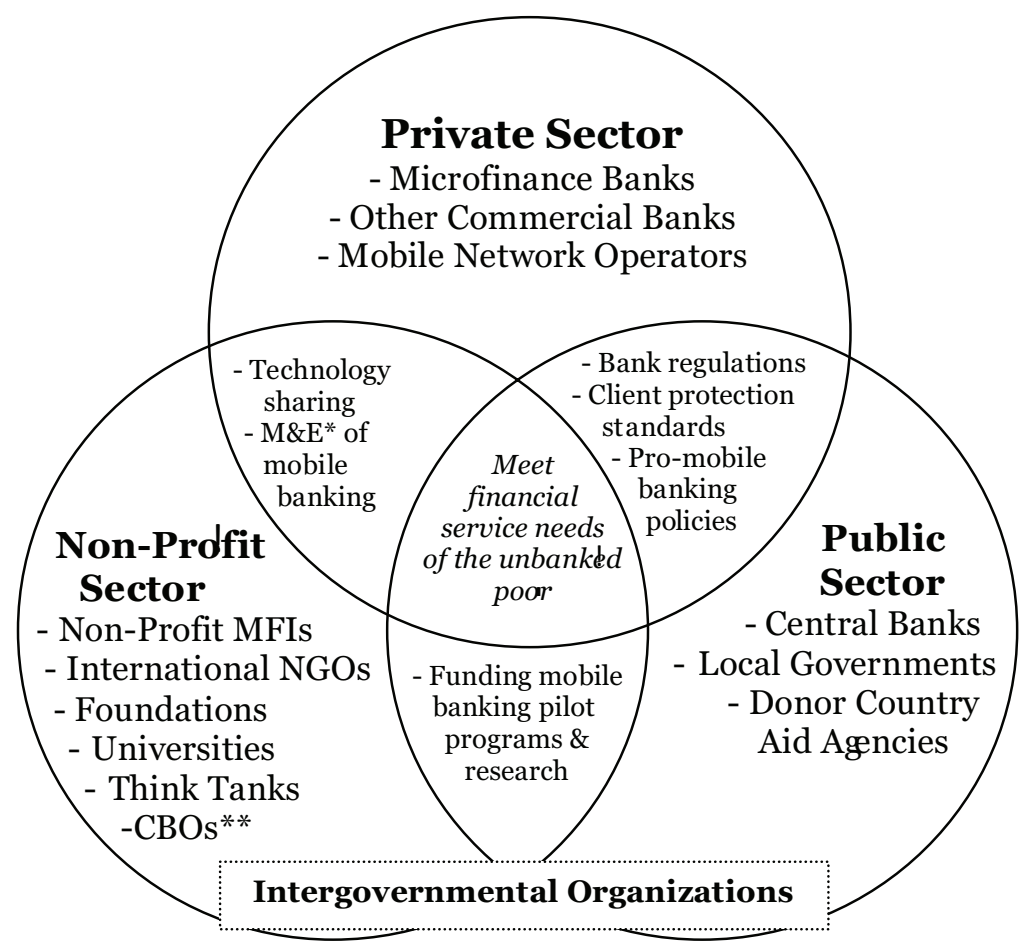

*Monitoring and Evaluation ${ }^{* *}$ Community Based Organizations

Source: Author's analysis. 
include services that facilitate savings, insurance, and loans on scales and at interest levels that are accessible to poor and low-income clients.

The four key principles that Collins et al. (2009) have established for developing formal financial services for the poor-reliability, convenience, flexibility, and structure - can be more easily and directly linked to mobile banking services. Assuming that clients have access to mobile phones and bank agents, financial transactions performed through mobile banking are by their very nature likely to be more reliable and structured than many informal financial services. The automated receipts produced by mobile phones make financial transactions more reliable, while the regulation of the businesses and organizations that implement the services provides structure. At the same time, these mobile banking services are likely to be more convenient and flexible than other formal bank services conducted by traditional banks.

The private sector can provide a greater percentage of the unbanked with a wider scope of services than non-profit microfinance institutions, but non-profit organizations and governments also play key roles in allowing mobile money services to meet the needs of the poor for reliable, convenient, flexible, and structured financial services. Though collaboration between sectors can expand the reach of mobile money, precautions must be taken to ensure that partnerships are built in productive ways. There are two ways in which the public sector and non-profit sector must collaborate with mobile banking service providers to ensure that mobile banking meets the financial needs of the unbanked poor. First, mobile banking service providers must be supported by agencies and organizations within the public and non-profit sectors to promote operational sustainability. Second, public and non-profit agents should act as watchdogs to measure the actual impact that such services have on individuals without prior access to formal financial services.

\section{Meeting the Financial Needs of the Poor through Cross-Sector Collaboration}

As the cases described in Kenya, the Philippines, the United States, Haiti, and India have shown, the public sector is capable of either playing an instrumental role in supporting mobile banking initiatives or creating significant obstacles to the success of mobile banking. The actual role of the public sector depends on relevant policies, regulations, and the actions of political leaders. Increasingly, the nonprofit sector has shown a considerable capacity for supporting, evaluating, and building on mobile banking initiatives currently run by the private sector. By identifying and building on the unique strengths of each sector and encouraging sectors to work in partnership, mobile banking innovations and developments are more likely to meet the financial needs of the unbanked poor. Figure 3 illustrates how collaboration is most likely to be effective among the three sectors.

Within the private sector, cooperation between banks and mobile network operators to create innovative and efficient mobile banking services demonstrates how collaboration has led to wider access to financial services. In order for these services to be implemented, however, mobile banking service providers require a supportive regulatory environment in the public sector. Central banks must consider how current bank regulations may affect the viability of mobile banking services. This is particularly important in the case of savings, as mobile network operators and/ or bank agents must legally be able to collect deposits for mobile microsavings to be feasible. Moreover, both national and local government agencies can support mobile banking by creating policies that support microfinance and encourage technological innovation as a means for reaching more unbanked clients. Lastly, the public sector must emphasize client protection and mobile banking services that improve the 
security of financial transactions, while ensuring that clients are not overburdened by the terms of the services. While government actors should encourage responsible practices among microfinance institutions and mobile banking service providers, the public sector should not create unnecessary bureaucratic oversights. Specifically, the concept of client protection must not be used merely for political gain and thorough research should assess how to best ensure client protection.

One core competency for nonprofit organizations, governments, and intergovernmental organizations (IGOs) is to identify and fund mobile banking initiatives that specifically target the unbanked. Foundations and bilateral aid agencies such as the Bill \& Melinda Gates Foundation and the Department for International Development illustrate this concept at work through funding pilot programs and encouraging mobile banking through competitive grants. While financial support for new mobile money services is extremely important, foundations and donor country agencies must first research which mobile money practices have most effectively reached the unbanked and the specific contexts behind each success.

In order to conduct such research effectively, mobile money services must be monitored and evaluated in terms of the economic and social impact. While the work of the Georgetown and MIT economists provides good examples of the social and economic trends associated with the usage of M-PESA services, more research is needed on the actual impact of mobile banking services on the lives of clients, including assessments of the strengths and weaknesses of mobile money service models in different countries. Financial institutions are capable of conducting the necessary market research, including appropriate marketing and the need for addressing financial literacy barriers, and mobile service operators can contribute access to recent innovative technology (Saxena 2009). Nonprofit organizations such as universities, think tanks, and other research institutions are best equipped to assess the implications of mobile money for international development. The public sector and IGOs can also become involved in monitoring and evaluating mobile banking initiatives by providing funding for such research.

While foundations can fund mobile banking initiatives and research institutions can monitor and evaluate the effectiveness of mobile banking services, private sector mobile banking service providers can also advance the goals of the non-profit sector. The private sector can increase the likelihood of mobile banking reaching the poorest of the poor by sharing best practices and providing non-profits with access to new technology. Non-profit organizations should seek out strategies for mobile banking to reach the unbanked poor who are not served by the private sector, rather than attempting to compete with private sector mobile banking service providers.

The United Nations World Food Programme has shown that by collaborating with the private sector, IGOs can utilize mobile banking to provide relief to victims of natural disasters and political conflicts. IGOs can also improve the regulatory environment for mobile banking by recognizing the value of mobile banking on a global scale and encouraging dialogue between member states about productive policies that allow mobile banking to serve unbanked populations.

\section{Conclusion}

It would be astute for private sector, public sector, or non-profit sector actors to consider the possibilities that innovative communication and transaction channels offer for microfinance, given the rate of technology advancement in both developed and developing countries. Since so many innovations such as M-PESA are relatively new, more research is needed on the long-term implications of such services for both providers and clients, and whether successful services in one country can be adapted to others. Ultimately, what remains most imp- 
portant is that the sectors involved in mobile banking service development join forces to ensure that the reach of microfinance expands in a sustained manner that remains in line with the needs of the unbanked poor.

Financial institutions, technology providers, government agencies, NGOs, and IGOs all play a role in developing the institutional capacity for microfinance. The public sector in particular must be responsible for forming policies and bank regulations that encourage mobile banking and client protection. The non-profit sector can provide independent monitoring and evaluation of the economic and social impacts of mobile banking services. To the extent that such services provide important and useful services for empowering the poor, governments and NGOs should tailor funding priorities and banking regulations to support the expansion of such services. Building off of the rapid growth of mobile banking services, private, public, and non-profit sectors can and should collaborate within countries towards expanding the reach of financial inclusion to meet the needs of the poor.

\section{References}

Akula, Vikram. 2009. "The time for mobile banking for financial inclusion is now." Hindustan Times, August 7. http://www.hindustantimes.com/News-Feed/india/ The-time-for-mobile-banking-for-financial-inclusion-is-now/Article1-441000. aspx.

Armendáriz de Aghion, Beatriz and Jonathan Morduch. 2005. The Economics of Microfinance. Cambridge, MA: MIT Press.

Banerjee, Abhijit, Esther Duflo, Rachel Glennerster and Cynthia Kinnan. 2010. ““The miracle of microfinance? Evidence from a randomized evaluation." Abdul Latif Jameel Poverty Action Lab (J-PAL) \& Center for Microfinance. June 30. http:// www.povertyactionlab.org/sites/default/files/publications/44-\%20June\%2O 2010.pdf.

Bellman, Eric and Arlene Chang. 2010. "India's Major Crisis in Microlending: Loans Involving Tiny Amounts of Money were a Good Idea, but the Explosion of Inter est Backfires.” Wall Street Journal, October 28. http://online.wsj.com/article/ SB10001424052702304316404575580663294846100.html.

BBC News. 2010. "Bill Gates offers \$10m fund for mobile banking in Haiti." June 9. http://www.bbc.co.uk/news/10273158.

Bold, Chris. 2011. "Haiti: Could mobile banking be the legacy of the earthquake?" CGAP Technology Blog, January 11. http://technology.cgap.org/2011/o1/11/haiticould-mobile-banking-be-a-legacy-of-the-earthquake/.

Christensen, Lisa Jones and Jessica Thomas. 2010. "Case Study: Jamii Bora.” Financial Times, December 8. http://www.ft.com/cms/s/o/17b820e4-030a-11eo-bb1eo0144feabdco.html\#axzz1H4aZ76LJ.

CNN. 2011. "Texting to Fight Hunger.” January 17. http://edition.cnn.com/video/\# / video/international/2011/01/17/wv.hunger.text.bk.g.cnn.

Collins, Daryl, Jonathan Morduch, Stuart Rutherford, and Orlanda Ruthven. 2009. Portfolios of the Poor: How the World's Poor Live on \$2 a Day. Princeton: Princeton University Press.

Crook, Jordan. 2009. "MoneyGram launches global mobile money transfer service." Mobile Marketer, August 4. http://www.mobilemarketer.com/cms/news/ banking-payments/3830.print. 
DFID (Department for International Development). 2008. "Vodafone UK/Global - MPesa (Mobile Money): Kenya and Tanzania.” National Archives, February 12. http://collections.europarchive.org/tna/20081202180014/www.financialdeepening.org/default.asp?id=694\&ver=1.

The Economist. 2010a. "Security for Shillings" March 11. http://www.economist.com/ node/15663856?story_id=15663856.

- - . 2010b. "Microfinance in India Discredited: A string of suicides puts microfinance under the spotlight." November 4.http://www.economist.com/node/17420202.

Globe. 2011. "DSWD through Landbank taps GCASH REMIT for distribution of cash grants to more areas nationwide: GCASH REMIT CCT pilot-run successful." AccessedApril1.http://site.globe.com.ph/web/gcash/news/news15?sid=TZX@ DMuxpRYAAHrLLB4AAAAXe.

Gordon, Jeremy. 2010. Photo of M-PESA mobile money on a phone. "Kiva Fellows Blog.” http://fellowsblog.kiva.org/2010/05/19/tomorrow-is-here-m-keshooffers-microloans-and-interest-via-mobile-phone/.

Greenwood, Louise. 2009. “Africa's mobile banking revolution.” BBC Africa Business Report, August 12. http://news.bbc.co.uk/2/hi/8194241.stm.

GSM Association. 2011. "The Deployment Tracker.” Mobile Money Exchange, March 20. http://www.wirelessintelligence.com/mobile-money.

ITU (International Telecommunication Union). 2010. The World in 2010: ICT Facts and Figures. http://www.itu.int/ITU-D/ict/material/FactsFigures2010.pdf.

-_-. 2011. "Market Information and Statistics." Mobile cellular subscriptions and esti mated Internet users. Last modified March 4. http://www.itu.int/ITU-D/ict/ statistics/.

Ivatury, Gautam and Ignacio Mas. 2008. "The early experience with branchless bank ing.” CGAP Focus Notes No. 46, April. http://www.cgap.org/p/site/c/template. rc/1.9.2640/.

Jack, William and Tavneet Suri. 2010b. “The Economics of M-PESA.” Working paper, August 2010. http://www.mit.edu/ tavneet/M-PESA.pdf.

-—-. 2010a. "The Economics of M-PESA: An Update.” Working paper, October 2010. http://www.mit.edu/ tavneet/M-PESA_Update.pdf.

Kazmin, Amy. 2011. "India pushes for national microfinance rules." Financial Times, January 19. http://www.ft.com/cms/s/o/89555e5c-23de-11eo-8bb1-00144fea b49a.html\#axzz1H4aZ76LJ.

Leishman, Paul. 2009. "Serving the unbanked... by serving the banked. Lessons from Safaricom, SMART, Global and Zain." Mobile Money for the Unbanked, GSM Association, September 4. http://mmublog.org/blog/serving-the-unbankedby-serving-the-banked-lessons-from-safaricom-smart-globe-and-zain/.

MacFarquhar, Neil. 2010. "Banks Making Big Profits From Tiny Loans." New York Times, April 13. http://www.nytimes.com/2010/04/14/world/14microfinance. html.

Mas, Ignacio and Hannah Siedek. 2008. "Banking through Networks of Retail Agents." CGAP Focus Notes No. 47, May. Accessed March 8, 2010. http://www.cgap. org/p/site/c/template.rc/1.9.3922/.

Mas, Ignacio and Olga Morawczynski. 2009. "Designing Mobile Money Services: Les sons from M- PESA.” Innovations 4.2: 77-91. Accessed March 8, 2010. http:// www.mitpressjournals.org/doi/pdf/10.1162/itgg.2009.4.2.77.

McKay, Claudia and Mark Pickens. 2010. "Branchless Banking: Who's Served? At What Price? What's Next?” CGAP Focus Notes No. 66, September. http://www.cgap. org/p/site/c/template.rc/1.9.47614/. 
Microfinance Focus. 2010. “Africa’s leading Microfinance Bank launches M-KESHO for M-PESA customers.” May 19. http://www.microfinancefocus.com/ news/2010/05/19/africa\%E2\%80\%99s-leading-microfinance-bank-launchesm-kesho-for-m-pesa-customers/.

microLINKS. 2011. "Haiti Integrated Finance for Value Chains and Enterprises (HIFIVE).” Last modified February 7. http://www.microlinks.org/ev_ en.php?ID=41315_201\&ID2=DO_TOPIC.

Mui, Ylan Q. 2011. "Retailers offer financial services to 'unbanked." Washington Post, January 31. http://www.washingtonpost.com/wp-dyn/content/arti cle/2011/01/31/AR2011013106177.html.

Pickens, Mark. 2009. "Window on the Unbanked: Mobile Money in the Phillipines." CGAP Brief, December. http://technology.cgap.org/2010/01/12/window-onthe-unbanked-mobile-money-in-the-philippines/.

- - . 2010. "Mobile money takes off... where is the innovation in product design?" CGAP Technology Blog, March 8. http://technology.cgap.org/2010/03/o8/ mobile-money-takes-off-where-is-the-innovation-in-product-design/.

"Republic Act No. 8791.” 2000. http://www.bsp.gov.ph/downloads/Regulations/gba .pdf.

Rhyne, Elisabeth. 2009. Microfinance for Bankers and Investors: Understanding the Opportunities and Challenges at the Bottom of the Pyramid. New York: Mc Graw-Hill.

- - . 2010. "On Microfinance: Who's to Blame for the Crisis in Andra Pradesh?” Huffington Post, November 2. http://www.huffingtonpost.com/elisabeth-rhyne/onmicrofinance-whos-to-b_b_777911.html.

Rotman, Sarah. 2011. “"We can’t have two mobile currencies circulating," says Globe President- Highlights and Headlines for January 2011." CGAP Technology Blog, January 27. http://technology.cgap.org/2011/o1/27/highlights-and-headlinesjanuary-2011/.

Rutherford, Stuart. 2001. The Poor and their Money. New Delhi: Oxford University Press.

Saxena, Amitabh. 2009. "Accelerating Financial Inclusion through Innovative Chan nels: 10 Obstacles for MFIs Launching Alternative Channels-and What Can Be Done About Them.” InSight 27: 1-21. http://www.centerforfinancialinclusion .org/Document.Doc?id=731.

Taylor, Erin B. 2011. "The rollout of mobile money in Haiti." Institute for Money, Tech nology and Financial Inclusion. Blog, January 24. http://www.imtfi.uci.edu/im tfi_haiti_blog_012411.

Todd, Helen. 1996. Women at the Center: Grameen Bank Borrowers After One Decade. Boulder, CO: Westview Press.

Trilogy International Partners. 2010. “Trilogy, Unibank \& Mercy Corps, a Team Effort to Launch Mobile Money in Haiti.” Mobile-Financial.com, September 23. http:// mobile-financial.com/node/12683.

United Nations Development Programme. 2009. Human Development Report 2009. Overcoming barriers: Human mobility and development. http://hdr.undp .org/en/media/HDR_2009_EN_Complete.pdf.

U.S. Census Bureau. 2010. America's Families and Living Arrangements: 2010. http:// www.census.gov/population/www/socdemo/hh-fam/cps2010.html.

Western Union. 2010. "Mobile money transfer fact sheet.” Accessed April 11, 2010. http://corporate.westernunion.com/news_media_MobileMoney.html.

World Bank. 2011. "Poverty headcount ratio at $\$ 2$ a day (PPP) (\% of population)." 
World Development Indicators. Accessed April 1. http://data.worldbank.org/ indicator/SI.POV.2DAY.

Yunus, Muhammad. 1999. Banker to the Poor: Micro-lending and the battle against world poverty. Jackson, TN: PublicAffairs.

\section{Notes}

1. The measurement of "two dollars per day" used here refers to \$2 (US) per day calculated in 2005 Purchasing Power Parity (PPP) terms. In other words, instead of referring to the market value of two dollars (US) in 2005, this "two dollar (US) 2005 PPP" measurement refers to the equivalent, in any other country, of the amount of basic goods and services that could be bought in the US for two dollars in 2005. All references made in this paper to living on an income of less than two dollars per day are based on 2005 Purchasing Power Parity terms regardless of the year and population in question.

Kanika Metre is a second year Master of Public Administration student at The George Washington University, concentrating in international development management. She earned a BA in 2009 from The George Washington University in international affairs and women's studies. She currently works as a graduate teaching assistant for the Elizabeth J. Somers Women's Leadership Program in international arts and culture. While a student at The George Washington University, she has also held internships with the Overseas Private Investment Corporation, ACCION International, International Relief \& Development, and the United Nations Development Programme. Following her graduation in May, she will begin a year-long internship in Indonesia as a 2011-2012 Luce Scholar.

The author would like to thank editors Meghan Wills, Joshua D. Nadas, Kaitlin Welborn, and Andrea Leung for their generosity with their time, constant encouragement, and constructive feedback. The author would also like to thank Professor Joan DudikGayoso for recommending the paper for publication and Professor Marvin Phaup for his additional insight during the editing process. Lastly, the author would like to thank her fellow ACCIONistas at ACCION International for piquing her interest in microfinance and mobile money. 